\title{
Predictors of Burnout, Job Satisfaction, and Turnover in Behavior Technicians Working with Individuals with Autism Spectrum Disorder
}

\author{
Marlena N. Novack ${ }^{1}$ (D) $\cdot$ Dennis R. Dixon ${ }^{1}$
}

Received: 2 August 2018 / Accepted: 10 April 2019 / Published online: 10 May 2019

(C) The Author(s) 2019

\begin{abstract}
Frequent turnover of behavior technicians working with individuals with autism spectrum disorder (ASD) may have negative impacts on organizations, staff, and patients. The current paper set out to conduct a systematic review of predictors of staff retention in behavior technicians. Two databases were searched to identify studies relating to retention, turnover, burnout, and job satisfaction across samples of behavior technicians working with individuals with ASD. Of the 33 articles identified, 5 studies met inclusion criteria. A number of employee and organizational factors were identified as predictors of burnout, job satisfaction, and intention to turnover in behavior technicians. These findings are informative for hiring practices, ongoing supervision, and support of behavior technicians working with individuals with ASD.
\end{abstract}

Keywords Autism spectrum disorder $\cdot$ Behavior technician $\cdot$ Retention $\cdot$ Burnout $\cdot$ Turnover $\cdot$ Job satisfaction

Applied behavior analysis (ABA) is a well-established treatment for autism spectrum disorder (ASD; Eldevik et al. 2009; Reichow 2012; Reichow et al. 2012). ABA has been found to effectively improve performance on measures of intellectual functioning, language, adaptive skills, and social skills for individuals with ASD (Eldevik et al. 2009; Makrygianni and Reed 2010; Peters-Scheffer et al. 2011; Reichow 2012; Reichow and Wolery 2009; Virues-Ortega 2010). Availability of behavioral providers to assist all those in need of services is an area of concern (Wise et al. 2010). Considering the intensive and one-to-one nature of ABAbased services, (Behavior Analyst Certification Board 2014; Eldevik et al. 2009; Reichow et al. 2012) as well as the latest reported prevalence rates of ASD, which estimate that 1 in 59 children in the USA are diagnosed (Autism and Developmental Disabilities Monitoring Network 2018), there is an increasing need for behavior technicians, the direct-care staff that conduct ABA-based treatment.

Typically, ABA-based treatment is supervised by master's or doctoral-level licensed and/or certified clinicians (e.g.,

Marlena N. Novack

m.novack@centerforautism.com

1 Center for Autism and Related Disorders, 21600 Oxnard Street, Suite 1800, Woodland Hills, California 91367, USA
Board Certified Behavior Analyst, marriage and family therapists, speech and language pathologist, etc.), who are responsible for assessing skill deficits, developing treatment plans, tracking progress, and adjusting treatment goals among other responsibilities (Behavior Analyst Certification Board 2014). Supervisors oversee behavior technicians, sometimes referred to as other titles (e.g., therapists, paraprofessionals, tutors, etc.), who are responsible for providing direct services to individuals with ASD. Behavior technicians typically have high school or bachelor's-level educations and are increasingly being required to obtain certification as they gain experience (e.g., Board Certified Autism Technician, Registered Behavior Technician; Behavior Analyst Certification Board 2014, Behavioral Intervention Certification Council 2015). Behavior technicians are responsible for implementing treatment plans, which are developed by the supervising clinician.

It is often assumed that behavior technician turnover is high; however, estimated rates of turnover for behavior technicians have not been reported. Examining turnover rates in similar professional fields may offer some insight. Rates of turnover for community-based direct-care staff working with individuals with developmental disabilities (DD) have been reported as high as $70.7 \%$ to $77 \%$ per year (Mitchell and Braddock 1994; Seninger and Traci 2002).

High turnover may have negative implications on organizations, staff, and patients with ASD. Training for behavior technicians is extensive, requiring large commitments of time 
and resources by both employers and employees. As in the health care industry, loss of productivity and costs of hiring and training new staff places a financial burden on providers (Waldman et al. 2004). Further, high turnover may also negatively impact remaining employees' morale and workload as experienced staff are replaced by untrained staff (Sulek et al. 2017). Finally, frequent turnover may disrupt the continuity of services, which may potentially have a negative impact on patients' progress in treatment.

Identifying predictors of turnover may be beneficial to service providers as it gives providers areas to address proactively to reduce turnover. Pertinent information may be gleaned from research on predictors of turnover and burnout in other demanding professions, like child welfare workers (DePanfilis and Zlotnik 2008; Kim and Kao 2014), directcare staff in services for individuals with intellectual disability (ID) and DD (Gray and Muramatsu 2013; Hatton et al. 2001), and special education teachers (Billingsley 2004; Brunsting et al. 2014); however, working specifically with individuals with ASD poses unique challenges. For instance, teachers working with children with ASD have been found to experience greater levels of burnout in comparison to teachers working with children with ID and children who are deaf (Zarafshan et al. 2013).

The primary purpose of this paper was to conduct a systematic review of predictors of staff retention and turnover for behavior technicians working with individuals with ASD. Due to the scarcity of this research, the current review was expanded to include predictors of burnout and job satisfaction as these factors have been linked to intention to turnover (Kim and Kao 2014). Findings of the current review should be informative for hiring practices, ongoing supervision, and support of behavior technicians working with individuals with ASD.

\section{Methods}

The databases PsycINFO and PubMed were searched. Results were limited to peer-reviewed articles with a publication year of 2000 or later. A combination of the following terms was used in the searches: "autism," "Asperger's," "pervasive developmental disorder," "therapists," "technicians," "paraprofessionals," "tutors," "staff," "direct care," "retention," "turnover," "burnout," and "job satisfaction."

The titles and abstracts of articles were initially reviewed for relevancy. The methods of relevant articles were reviewed and the article was included if the following criteria were met: (a) was a research study; (b) participants included behavior technicians providing ABA to individuals with ASD; and (c) retention, turnover, burnout, or job satisfaction was a dependent variable. While these procedures may not have produced an exhaustive review, findings should be representative of factors associated with retention, turnover, burnout, and job satisfaction in behavior technicians.

Interobserver agreement (IOA) data were collected for study inclusion. The authors independently followed the procedures discussed previously for study inclusion. Percentage of agreement was calculated by dividing the total number of agreements by the total number of agreements plus disagreements and multiplying by 100 (Kazdin 1982). IOA for study inclusion was $96.9 \%$ (i.e., the authors disagreed on one article). The disagreement was discussed and resolved. Procedures were also in place to verify the data collected from the included studies. One author extracted data from the studies (i.e., sample size, setting, methods, dependent variables and measures, independent variables found to be significant, independent variables found to be insignificant). The second author reviewed and verified the extracted data. Any disagreements between the authors were resolved via discussion.

\section{Results}

A literature search of PsycINFO identified 31 publications and a literature search of PubMed identified 11 publications. After duplicates were removed, the titles and abstracts of 33 articles were screened. A total of 21 articles were found to be potentially relevant. Methods were reviewed for eligibility and only five articles met the inclusion criteria. Of the 16 articles that were excluded, 10 were excluded because samples did not include behavior technicians providing ABA to individuals with ASD; 4 were excluded because retention, turnover, burnout, or job satisfaction was not a dependent variable; and 2 reviews of literature were excluded. See Fig. 1 for a flow diagram of the search results and Table 1 for summaries of the included studies.

\section{Participants}

Participants across all the reviewed studies included a total of 351 behavior technicians working with individuals with ASD. Samples of participants were predominately female, ranging between $89 \%$ and $100 \%$ female across studies. Three of the studies provided the geographical region where their sample of participants worked, which included California (Kazemi et al. 2015), Ireland (Gibson et al. 2009), and the United Kingdom (Griffith et al. 2014). The behavior technicians worked in home (Hurt et al. 2013; Kazemi et al. 2015) and school settings (Gibson et al. 2009; Griffith et al. 2014; Kazemi et al. 2015; Kelly and Barnes-Holmes 2013). All studies included behavior technicians practicing ABA; however, a portion of the sample included in Hurt et al. (2013) practiced other therapeutic methods (e.g., Floortime, pivotal response training, Treatment and Education of Autistic and Related Communication Handicapped Children). Finally, 


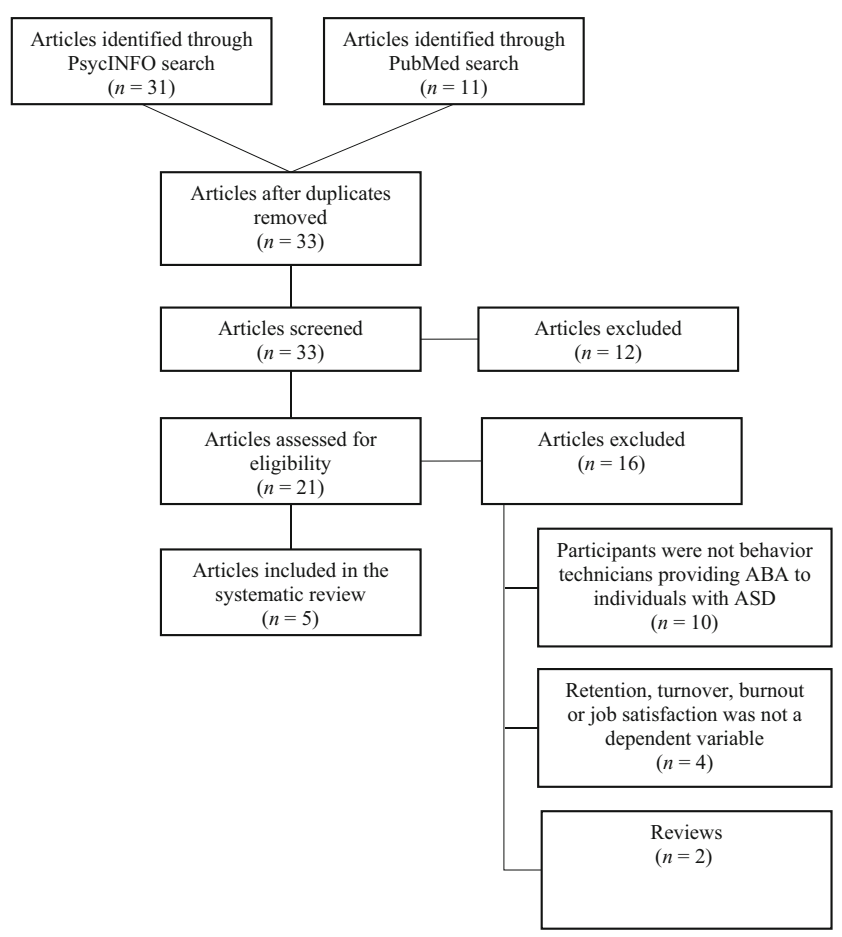

Fig. 1 Results of systematic literature searches

portions of the samples in Gibson et al. (2009) and Griffith et al. (2014) were reported to have supervisor-level roles (e.g., lead therapist, supervisor).

\section{Methods}

All the reviewed studies administered survey questionnaires or batteries of measures to samples of behavior technicians (Gibson et al. 2009; Griffith et al. 2014; Hurt et al. 2013; Kazemi et al. 2015; Kelly and Barnes-Holmes 2013). One study also administered a computer-based task to participants (Kelly and Barnes-Holmes 2013).

\section{Dependent Variables and Measures}

To be included, the reviewed studies must have explored turnover, burnout, and/or job satisfaction as a dependent variable. Burnout was explored most often and was included as a dependent variable in four of the studies (Gibson et al. 2009; Griffith et al. 2014; Hurt et al. 2013; Kelly and Barnes-Holmes 2013). To evaluate burnout across participants, two of the included studies (Gibson et al. 2009; Griffith et al. 2014) used the Maslach Burnout Inventory (MBI; Maslach et al. 1986). The $M B I$ assesses three components of burnout: emotional exhaustion (i.e., feeling emotionally overextended by one's occupation), depersonalization (feeling impersonal towards those receiving one's services or care), and personal accomplishment (feeling capable and successful in one's occupation). The remaining studies used different versions of the $M B I$ to measure burnout. Kelly and Barnes-Holmes

Table 1 Summary of reviewed studies

\begin{tabular}{|c|c|c|c|c|c|}
\hline Authors & Sample Size & Setting & Methods & $\begin{array}{l}\text { Dependent } \\
\text { variable(s) }\end{array}$ & Results \\
\hline $\begin{array}{l}\text { Gibson et } \\
\text { al. (2009) }\end{array}$ & $\begin{array}{l}81 \text { behavior } \\
\text { technicians }\end{array}$ & $\begin{array}{l}11 \text { ABA schools } \\
\text { in Ireland }\end{array}$ & Questionnaires & Burnout & $\begin{array}{l}\text { Perceived supervisor support predicted } \\
\text { lower levels of burnout and was found to } \\
\text { moderate the effects of perceived } \\
\text { work demands on burnout. }\end{array}$ \\
\hline $\begin{array}{l}\text { Griffith et } \\
\text { al. (2014) }\end{array}$ & $\begin{array}{l}45 \text { behavior } \\
\text { technicians }\end{array}$ & $\begin{array}{l}\text { Six ABA schools } \\
\text { in the UK }\end{array}$ & Questionnaires & Burnout & $\begin{array}{l}\text { Wishful-thinking coping was found } \\
\text { to be a predictor of burnout. }\end{array}$ \\
\hline $\begin{array}{l}\text { Hurt et } \\
\text { al. (2013) }\end{array}$ & $\begin{array}{l}113 \text { behavior } \\
\text { technicians } \\
\text { conducting ABA or } \\
\text { other therapeutic } \\
\text { approaches }\end{array}$ & $\begin{array}{l}\text { Home-based } \\
\text { services }\end{array}$ & Questionnaires & $\begin{array}{l}\text { Burnout; job } \\
\text { satisfaction }\end{array}$ & $\begin{array}{l}\text { Extraversion was found to be a protective } \\
\text { factor and neuroticism was found to be a risk } \\
\text { factor for burnout and job satisfaction. } \\
\text { Perceived supervisor support was found } \\
\text { to partially mediate the effects of } \\
\text { personality traits on job satisfaction. }\end{array}$ \\
\hline $\begin{array}{l}\text { Kazemi et } \\
\text { al. (2015) }\end{array}$ & $\begin{array}{l}96 \text { behavior } \\
\text { technicians }\end{array}$ & $\begin{array}{l}19 \text { ABA agencies in } \\
\text { Southern } \\
\text { California }\end{array}$ & Questionnaires & $\begin{array}{c}\text { Intention to } \\
\text { turnover }\end{array}$ & $\begin{array}{l}\text { Job satisfaction and satisfaction with } \\
\text { training and supervision were related } \\
\text { to intention to turnover. While satisfaction } \\
\text { with pay and reports of being under } \\
\text { scheduled were associated with intention } \\
\text { to turnover, objective measures of pay } \\
\text { and hours worked were not found to be } \\
\text { related. }\end{array}$ \\
\hline $\begin{array}{l}\text { Kelly and } \\
\text { Barnes-Hol- } \\
\text { mes, (2013) }\end{array}$ & $\begin{array}{l}16 \text { behavior } \\
\text { technicians }\end{array}$ & One ABA school & $\begin{array}{l}\text { Questionnaires and a } \\
\text { computer-based } \\
\text { task }\end{array}$ & Burnout & $\begin{array}{l}\text { Negative implicit attitudes towards individuals } \\
\text { with ASD were found to correlate with } \\
\text { burnout. }\end{array}$ \\
\hline
\end{tabular}


(2013) used the MBI - Educators Survey (Maslach et al. 1996) and Hurt et al. (2013) used the MBI-General Survey (Schaufeli et al. 1996). The MBI-GS measures slightly different components of burnout (i.e., exhaustion, cynicism, and personal efficacy).

Intention to turnover was included as a dependent variable in one study (Kazemi et al. 2015). To measure intention to turnover, Kazemi et al. (2015) used two items from Dupre and Day (2007): (1) "I will leave my job if another job becomes available," and (2) "I will stay at my job for as long as I can." Finally, job satisfaction was included as a dependent variable in one study (Hurt et al. 2013). Hurt et al. (2013) used the Andrews and Withey Job Satisfaction Scale (Andrews and Withey 1976) to measure job satisfaction.

\section{Descriptive Data}

The studies provided some descriptive data on their samples of behavior technicians. Of the behavior technicians sampled by Kazemi et al. (2015), 38\% reported being highly or somewhat likely to resign. While low levels of overall burnout were found in behavior technicians working in ABA schools (Gibson et al. 2009), as high as $42 \%$ of behavior technicians were found to have low levels of personal accomplishment (Griffith et al. 2014), and as high as $27 \%$ were found to have high levels of emotional exhaustion (Gibson et al. 2009). High levels of depersonalization was not common across samples of behavior technicians (Gibson et al. 2009; Griffith et al. 2014).

\section{Predictor Data}

The independent variables evaluated in the reviewed studies can be broken down into employee-related variables, organizational variables, and patient- and student-related variables. Each is discussed in turn.

\section{Employee Factors}

All of the studies addressed various employee-related factors; see Table 2 for a detailed summary. Several employee-related factors have been identified as significant.

Personality traits were found to be correlated with burnout and job satisfaction in behavior technicians providing homebased services (Hurt et al. 2013). Four personality traits were found to be correlated with burnout. Extraversion, agreeableness, and conscientiousness were found to be protective traits while neuroticism was correlated with greater levels of burnout. Two personality traits were found to be associated with job satisfaction, with extraversion showing a positive correlation and neuroticism a negative correlation (Hurt et al. 2013).

Table 2 Summary of employee variables

\begin{tabular}{|c|c|c|}
\hline Variable & Significant & Not significant \\
\hline Attitudes towards ASD & $\begin{array}{l}\text { Increased negative implicit attitudes towards } \\
\text { children with ASD were correlated with } \\
\text { greater levels of burnout } \\
\text { (Kelly and Barnes-Holmes 2013). }\end{array}$ & $\begin{array}{l}\text { Positive implicit attitudes towards children } \\
\text { with ASD were not found to be correlated } \\
\text { with burnout (Kelly and Barnes-Holmes 2013). }\end{array}$ \\
\hline Attitudes towards TD & $\begin{array}{l}\text { Increased positive implicit attitudes towards } \\
\text { children with TD were found to be correlated } \\
\text { with lower levels of the emotional exhaustion } \\
\text { component of burnout (Kelly and Barnes-Holmes 2013). }\end{array}$ & $\begin{array}{l}\text { Negative implicit attitudes towards children with } \\
\text { TD were not found to be correlated with } \\
\text { burnout (Kelly and Barnes-Holmes 2013). }\end{array}$ \\
\hline Commitment to philosophy & $\begin{array}{l}\text { Greater commitment to philosophy was correlated } \\
\text { with greater levels of the personal accomplishment } \\
\text { component of burnout (Gibson et al. 2009). }\end{array}$ & $\mathrm{n} / \mathrm{a}$ \\
\hline Coping & $\begin{array}{l}\text { Wishful-thinking coping was correlated with higher } \\
\text { levels of burnout (Griffith et al. 2014). }\end{array}$ & $\begin{array}{l}\text { Practical coping was not found to be correlated } \\
\text { with burnout (Griffith et al. 2014). }\end{array}$ \\
\hline $\begin{array}{l}\text { Demographic variables (age, } \\
\text { education, experience) }\end{array}$ & $\mathrm{n} / \mathrm{a}$ & $\begin{array}{l}\text { Not found to be correlated with intention to turnover } \\
\text { (Kazemi et al. 2015) or burnout (Gibson et al. 2009; } \\
\text { Griffith et al. 2014; Hurt et al. 2013). }\end{array}$ \\
\hline Personality traits & $\begin{array}{l}\text { Extraversion, agreeableness, and conscientiousness } \\
\text { were associated with lower levels of burnout while } \\
\text { neuroticism was correlated with greater levels of burnout. } \\
\text { Extraversion was also correlated with greater job } \\
\text { satisfaction } \\
\text { while neuroticism was correlated with lower } \\
\text { job satisfaction (Hurt et al. 2013). }\end{array}$ & $\begin{array}{l}\text { Openness was not found to be correlated with burnout or } \\
\text { job satisfaction (Hurt et al. 2013). }\end{array}$ \\
\hline Self-efficacy & $\begin{array}{l}\text { Greater self-efficacy was correlated with higher levels of the } \\
\text { personal accomplishment component } \\
\text { of burnout (Gibson et al. 2009). }\end{array}$ & $\mathrm{n} / \mathrm{a}$ \\
\hline
\end{tabular}


Implicit attitudes towards children with ASD and typical development (TD) were also found to be significantly correlated with burnout in behavior technicians working in an ABA school (Kelly and Barnes-Holmes 2013). Increased implicit negative attitudes towards children with ASD were found to be positively correlated with burnout, and increased positive attitudes towards children with TD were found to be negatively correlated with burnout. On the other hand, both positive attitudes towards children with ASD and negative attitudes towards children with TD were not found to be correlated with burnout (Kelly and Barnes-Holmes 2013).

Other factors were found to be related to burnout in behavior technicians working in ABA schools. Coping strategies were found to be significant. Particularly, wishful-thinking coping was found to be associated with greater levels of burnout (Griffith et al. 2014). In addition, Gibson et al. (2009) found both commitment to philosophy and perceived therapeutic self-efficacy to be protective against burnout (Gibson et al. 2009).

General demographic factors (i.e., age, education, experience) were not found to be related to burnout (Gibson et al. 2009; Griffith et al. 2014; Hurt et al. 2013) or intention to turnover (Kazemi et al. 2015) in behavior technicians.

\section{Organizational Factors}

Organizational factors were investigated by four of the studies (Gibson et al. 2009; Griffith et al. 2014; Hurt et al. 2013; Kazemi et al. 2015). Table 3 provides a summary of the organizational factors explored in the reviewed research.

Supervisor support was given the most attention across the reviewed research. Greater satisfaction with supervisor support was found to be associated with lower levels of burnout (Gibson et al. 2009; Hurt et al. 2013), greater levels of job satisfaction (Hurt et al. 2013), and less intention to turnover (Kazemi et al. 2015). Perceived supervisor support was also found to moderate the effects of work demands on burnout (Gibson et al. 2009) and partially mediate the effects of personality traits on job satisfaction (Hurt et al. 2013). Findings on the significance of supervisor support were not entirely consistent. Perceived supervisor support was not found to be associated with burnout in a sample of behavior technicians working in ABA schools (Griffith et al. 2014). Griffith et al. (2014) suggest that their contrasting findings may be due to including a greater portion of behavior technicians with supervisor-level roles as compared to Gibson et al. (2009), and the authors speculate that supervisor support may have less of an impact on those behavior technicians.

Table 3 Summary of organizational variables

\begin{tabular}{|c|c|c|}
\hline Variable & Significant & Not significant \\
\hline Benefits & $\mathrm{n} / \mathrm{a}$ & $\begin{array}{l}\text { Not found to be correlated with intention to turnover } \\
\text { (Kazemi et al. 2015). }\end{array}$ \\
\hline Hours & $\begin{array}{l}\text { Reports of being under scheduled were correlated } \\
\text { with intention to turnover (Kazemi et al. 2015). }\end{array}$ & $\begin{array}{l}\text { Number of hours worked per week and reports of being } \\
\text { over scheduled were not found to be correlated with } \\
\text { intention to turnover (Kazemi et al. 2015). }\end{array}$ \\
\hline Job satisfaction & $\begin{array}{l}\text { Greater levels of job satisfaction were correlated } \\
\text { with less intention to turnover (Kazemi et al. 2015) } \\
\text { and lower levels of burnout (Hurt et al. 2013). }\end{array}$ & $\mathrm{n} / \mathrm{a}$ \\
\hline Pay & $\begin{array}{l}\text { Higher levels of satisfaction with pay were associated } \\
\text { with less intention to turnover (Kazemi et al. 2015). }\end{array}$ & $\begin{array}{l}\text { Wages earned per hour were not found to be correlated } \\
\text { with intention to turnover (Kazemi et al. 2015). }\end{array}$ \\
\hline Setting of services & $\mathrm{n} / \mathrm{a}$ & $\begin{array}{l}\text { Setting of services (e.g., home, school) was not found to } \\
\text { be correlated with intention to turnover (Kazemi et al. 2015). }\end{array}$ \\
\hline Supervisor support & $\begin{array}{l}\text { Greater levels of satisfaction with supervision were related } \\
\text { to lower intention to turnover (Kazemi et al. 2015). } \\
\text { Stronger perceived support from a supervisor was } \\
\text { correlated with lower levels of burnout (Gibson et al. 2009; } \\
\text { Hurt et al. 2013). Greater levels of personal and professional } \\
\text { support from a supervisor were correlated with greater } \\
\text { job satisfaction (Hurt et al. 2013). }\end{array}$ & Not found to be correlated with burnout (Griffith et al. 2014). \\
\hline Training & $\begin{array}{l}\text { Higher levels of satisfaction with training were related to lower } \\
\text { intention to turnover (Kazemi et al. 2015). }\end{array}$ & $\mathrm{n} / \mathrm{a}$ \\
\hline Travel time & $\mathrm{n} / \mathrm{a}$ & $\begin{array}{l}\text { Not found to be correlated with intention to turnover } \\
\text { (Kazemi et al. 2015). }\end{array}$ \\
\hline Work demands & $\begin{array}{l}\text { Excessive perceived work demands were correlated with higher } \\
\text { levels of the emotional exhaustion component of } \\
\text { burnout (Gibson et al. 2009). }\end{array}$ & \\
\hline
\end{tabular}


Contrasting findings emerged between objective measures versus subjective measures of a couple organizational variables. While report of being under scheduled was correlated with intention to turnover in behavior technicians, the number of hours worked per week was not found to be correlated with intention to turnover (Kazemi et al. 2015). Likewise, level of satisfaction with pay was negatively correlated with intention to turnover; however, wages earned per hour were not found to be correlated with intention to turnover (Kazemi et al. 2015).

Other factors were identified as being related to burnout and intention to turnover in behavior technicians. Level of satisfaction with training was negatively correlated with intention to turnover (Kazemi et al. 2015). High levels of perceived work demands were correlated with greater levels of burnout (Gibson et al. 2009). Finally, greater levels of job satisfaction were found to be associated with less intention to turnover (Kazemi et al. 2015) and lower levels of burnout (Hurt et al. 2013).

Several factors were investigated and not found to be significant predictors. Receipt of benefits and number of hours spent traveling were not found to be correlated with intention to turnover (Kazemi et al. 2015). Furthermore, setting of treatment services (e.g., home, school) was not found to be a predictor of intention to turnover (Kazemi et al. 2015).

\section{Patient and Student Factors}

Variables relating to patients and students were explored the least in the reviewed studies. Only two studies evaluated patient- and student-related factors (Gibson et al. 2009; Kazemi et al. 2015). See Table 4 for a summary of patientand student-related factors. None of the evaluated factors (i.e., age, ASD severity, and time spent working with student) were found to be significant variables.

\section{Discussion}

The purpose of the current paper was to review research on predictors of staff retention, turnover, burnout, and job satisfaction for behavior technicians working with individuals with ASD. A total of five articles were identified and reviewed.

None of the studies reported on rates of turnover in their samples of behavior technicians; however, Kazemi et al.
(2015) reported that $38 \%$ of the behavior technicians in their sample indicated that they were highly or somewhat likely to resign. While this may seem high in comparison to annual voluntary resignation rates reported in the total workforce (i.e., 26\%; Bureau of Labor Statistics 2018), it is much lower than annual turnover rates reported for directcare staff of individuals with DD (i.e., $70.7 \%$ to $77 \%$; Mitchell and Braddock 1994; Seninger and Traci 2002). Participants in the included studies were also found to have low levels of burnout as compared to normative data (Gibson et al. 2009). It should be noted that participation in the included studies was voluntary and thus the findings are reflective of staff who are motivated to participate in research. It is unknown if intention to turnover or level of burnout differed between staff who did and did not volunteer to participate (Griffith et al. 2014; Kazemi et al. 2015). Despite this limitation of the reviewed studies, the predictors identified in the studies have important implications. A number of employee and organizational factors were found to be associated with burnout, job satisfaction, and intention to turnover in behavior technicians.

One strategy for improving staff retention is considering whether an organization's hiring practices are identifying potential employees who are a good fit for the position. While education and experience are often given weight during the hiring process, such demographic variables were not found to be significant with respect to burnout (Gibson et al. 2009; Griffith et al. 2014; Hurt et al. 2013) or intention to turnover (Kazemi et al. 2015) in behavior technicians.

Measurement of character traits of perspective employees may be informative to the hiring process. Preliminary evidence suggests that personality traits (Hurt et al. 2013) and negative implicit attitudes towards children with ASD (Kelly and Barnes-Holmes 2013) are associated with burnout in behavior technicians. Future research should investigate whether such assessments of character traits are associated with turnover. In addition to burnout, behavior technician personality factors and attitudes towards individuals with disabilities have been linked to procedural fidelity (Peters-Scheffer et al. 2013). Staff retention is just one factor of importance to employers. Treatment fidelity and patient outcomes are also highly significant priorities. Tools that may identify job candidates that are less likely to turnover and more likely to have high
Table 4 Summary of patient and student variables

\begin{tabular}{llc}
\hline Variable & Significant & Not significant \\
\hline Age & $\mathrm{n} / \mathrm{a}$ & $\begin{array}{c}\text { Not found to be correlated with intention } \\
\text { to turnover (Kazemi et al. 2015). }\end{array}$ \\
ASD severity & $\mathrm{n} / \mathrm{a}$ & $\begin{array}{c}\text { Not found to be correlated with intention to } \\
\text { turnover (Kazemi et al. 2015). }\end{array}$ \\
Time spent working with student & $\mathrm{n} / \mathrm{a}$ & $\begin{array}{c}\text { Not found to be correlated with burnout } \\
\text { (Gibson et al. 2009). }\end{array}$ \\
\hline
\end{tabular}


procedural fidelity are worthy areas of future exploration. Such tools may also be helpful for identifying existing employees who are in need of additional support.

Another strategy for improving retention is evaluating whether ongoing organizational practices play a role in staff retention. Findings of the current review suggest that employers should give special consideration to ongoing support of their staff. For instance, incorporating evidence-based interventions to improve coping strategies (Griffith et al. 2014) and self-efficacy (Gibson et al. 2009) may be beneficial.

Perceived supervisor support received the most attention across the included studies and was found to be correlated with burnout (Gibson et al. 2009; Hurt et al. 2013), job satisfaction (Hurt et al. 2013), and intention to turnover (Kazemi et al. 2015). While perceived supervisor support was not always found to be significant (Griffith et al. 2014), overall, it appears to be meaningful. Perceived supervisor support was even found to moderate the effects of work demands on burnout (Gibson et al. 2009) and partially mediate the effects of personality traits on job satisfaction (Hurt et al. 2013). Perceived supervisor support was also found to increase selfefficacy in behavior technicians (Gibson et al. 2009). Given the benefits of perceived supervisor support, future research should investigate variables that may result in improved satisfaction with supervision in behavior technicians (e.g., frequency of clinic meetings and mentor meetings, management style).

While staff training was only directly explored by one of the reviewed articles, it may be a promising area for further investigation. Kazemi et al. (2015) found greater levels of satisfaction with training to be correlated with less intention to turnover in behavior technicians and found satisfaction with staff training to correlate with reported hours of initial training with $30 \mathrm{~h}$ or more corresponding with satisfaction. Furthermore, the significance of commitment to philosophy on burnout and self-efficacy may signify that theoreticalfocused training, as opposed to procedural-focused training, may be beneficial (Gibson et al. 2009).

Like satisfaction with supervision and training, organizational variables were often measured via employee perception. In some cases, both subjective and objective measures of organizational variables were explored. For instance, satisfaction with pay was found to be a predictor of intent to turnover; however, actual pay did not correlate with satisfaction of pay and actual pay was not found to be a predictor of intention to turnover (Kazemi et al. 2015). Similarly, report of being under scheduled was correlated with intention to turnover in behavior technicians while number of hours worked per week was not found to be correlated with intention to turnover (Kazemi et al. 2015). Contrasting findings between objective measures versus subjective measures help to illuminate the subjective nature of these drivers of intention to turnover. It appears that an individualized approach may be beneficial. For instance, considering the percentage of an employee's available hours worked per week may be more valuable than considering their total number of hours worked.

Patient- and student-related factors were explored the least in the reviewed research. Although no factors were identified as significant (Gibson et al. 2009; Kazemi et al. 2015), this area may warrant further investigation. Challenging behaviors, for instance, have been found to impact burnout in special education teachers and support staff of individuals with ID (Hastings and Brown 2002). While behavior technician report of ASD severity was not found to be a predictor of intention to turnover (Kazemi et al. 2015), ASD severity as measured on standardized assessments and child progress may warrant future investigation. Future research should explore whether various patient characteristics (challenging behaviors, symptom severity, rate of progress) contribute to turnover. Such findings may be helpful when considering case assignment, particularly for newly hired behavior technicians.

Some limitations should be considered when interpreting the findings of the current review. First, research evaluating predictors of job retention, turnover, burnout, and job satisfaction in behavior technicians is sparse. For the most part, findings have not been replicated and should be interpreted with caution. In addition, the current review included behavior technicians working in diverse settings. While treatment setting was not found to be related to intention to turnover (Kazemi et al. 2015), school and home settings certainly place differing work demands on behavior technicians. Another limitation is that the behavior technicians in this review were from diverse geographical regions, which may impact the samples differently (e.g., laws concerning work conditions). Finally, no studies investigated actual turnover in behavior technicians. While predictors of burnout, job satisfaction, and intention to turnover were identified in the current review, it is unknown whether these factors are truly related to staff retention. Longitudinal and retrospective analyses of predictors of actual turnover are warranted. Nevertheless, the current review gives meaningful recommendations for how employers may improve their practices.

\section{Compliance with Ethical Standards}

Conflict of Interest The authors declare that they have no conflicts of interest.

Open Access This article is distributed under the terms of the Creative Commons Attribution 4.0 International License (http:// creativecommons.org/licenses/by/4.0/), which permits unrestricted use, distribution, and reproduction in any medium, provided you give appropriate credit to the original author(s) and the source, provide a link to the Creative Commons license, and indicate if changes were made. 


\section{References}

*References marked with an asterisk indicate studies included in the review.

Andrews, F. M., \& Withey, S. B. (1976). Social indicators of well-being: Americans' perceptions of life quality. New York, NY: Plenum Press.

Autism and Developmental Disabilities Monitoring Network. (2018). Prevalence of autism spectrum disorder among children aged 8 years - Autism and Developmental Disabilities Monitoring Network, 11 sites, United States, 2014. Morbidity and Mortality Weekly Report. Surveillance Summaries, 67, 1-23. https://doi.org/10.15585/mmwr. ss6706a1.

Behavior Analyst Certification Board, Inc. (2014). Applied behavior analysis treatment of autism spectrum disorder: practice guidelines for healthcare funders and managers (2nd ed.). Retrieved from https://www.bacb.com/wp-content/uploads/2017/09/ABA_ Guidelines_for_ASD.pdf

Behavioral Intervention Certification Council. (2015). Board Certified Autism Technician candidate handbook. Retrieved from https:// www.behavioralcertification.org/Content/Downloads/BCAT CANDIDATE_HANDBOOK.pdf

Billingsley, B. S. (2004). Special education teacher retention and attrition: a critical analysis of the research literature. The Journal of Special Education, 38, 39-55. https://doi.org/10.1177/ 00224669040380010401.

Brunsting, N. C., Sreckovic, M. A., \& Lane, K. L. (2014). Special education teacher burnout: a synthesis of research from 1979 to 2013. Education and Treatment of Children, 37, 681-712. https://doi.org/ 10.1353/etc.2014.0032.

Bureau of Labor Statistics. (2018). Job openings and labor turnoverJanuary 2018. Retrieved from https://www.bls.gov/news.release/ archives/jolts_03162018.pdf

DePanfilis, D., \& Zlotnik, J. L. (2008). Retention of front-line staff in child welfare: a systematic review of research. Children and Youth Services Review, 30, 995-1008. https://doi.org/10.1016/j. childyouth.2007.12.017.

Dupre, K. E., \& Day, A. L. (2007). The effects of supportive management and job quality on the turnover intention and health of military personnel. Human Resource Management, 46, 185-201. https:// doi.org/10.1002/hrm.20156.

Eldevik, S., Hastings, R. P., Hughes, J. C., Jahr, E., Eikeseth, S., \& Cross, S. (2009). Meta-analysis of early intensive behavioral intervention for children with autism. Journal of Clinical Child and Adolescent Psychology, 38, 439-450. https://doi.org/10.1080/ 15374410902851739 .

*Gibson, J. A., Grey, I. M., \& Hastings, R. P. (2009). Supervisor support as a predictor of burnout and therapeutic self-efficacy in therapists working in ABA schools. Journal of Autism and Developmental Disorders, 39, 1024-1030. Doi: https://doi.org/10.1007/s10803009-0709-4

Gray, J. A., \& Muramatsu, N. (2013). When the job has lost its appeal: intentions to quit among direct care workers. Journal of Intellectual \& Developmental Disability, 38, 124-133. https://doi.org/10.3109/ 13668250.2012 .760728 .

*Griffith, G. M., Barbakou, A., \& Hastings, R. P. (2014). Coping as a predictor of burnout and general health in therapists working in ABA schools. European Journal of Special Needs Education, 29, 548-558. Doi: https://doi.org/10.1080/08856257.2014.952915

Hastings, R. P., \& Brown, T. (2002). Coping strategies and the impact of challenging behaviors on special educators burnout. Mental Retardation, 40, 148-156. https://doi.org/10.1352/00476765(2002)040<0148:CSATIO >2.0.CO;2.
Hatton, C., Emerson, E., Rivers, M., Mason, H., Swarbrick, R., Mason, L., et al. (2001). Factors associated with intended staff turnover and job search behaviour in services for people with intellectual disability. Journal of Intellectual Disability Research, 45, 258-270.

*Hurt, A. A., Grist, C. L., Malesky, L. A., \& McCord, D. M. (2013). Personality traits associated with occupational 'burnout' in ABA therapists. Journal of Applied Research in Intellectual Disabilities, 26, 299-308. doi: https://doi.org/10.1111/jar.12043

Kazdin, A. (1982). Single-case research designs: methods for clinical and applied settings. New York, NY: Oxford Press University.

*Kazemi, E., Shapiro, M., \& Kavner, A. (2015). Predictors of intention to turnover in behavior technicians working with individuals with autism spectrum disorder. Research in Autism Spectrum Disorder, 17, 106-115. doi: https://doi.org/ 10.1016/j.rasd.2015.06.012

*Kelly, A., \& Barnes-Holmes, D. (2013). Implicit attitudes towards children with autism versus normally developing children as predictors of professional burnout and psychopathology. Research in Developmental Disabilities, 34, 17-28. doi: https://doi.org/10. 1016/j.ridd.2012.07.018

Kim, H., \& Kao, D. (2014). A meta-analysis of turnover intention predictors among U.S. child welfare workers. Children and Youth Services Review, 47, 214-223. https://doi.org/10.1016/j.childyouth. 2014.09.015.

Makrygianni, M. K., \& Reed, P. (2010). A meta-analytic review of the effectiveness of behavioural early intervention programs for children with autism spectrum disorders. Research in Autism Spectrum Disorders, 4, 577-593. https://doi.org/10.1016/j.rasd.2010.01.014.

Maslach, C., Jackson, S. E., \& Leiter, M. P. (1986). Maslach burnout inventory manual (2nd ed.). Palo Alto: Consulting Psychologists Press.

Maslach, C., Jackson, S. E., \& Schwab, R. L. (1996). Maslach burnout inventory - educators survey (MBI-ES). In C. Maslach, S. E. Jackson, \& M. P. Leiter (Eds.), Maslach burnout inventory manual (3rd ed.). Palo Alto: Consulting Psychologists Press.

Mitchell, D., \& Braddock, D. (1994). Compensation and turnover of direct-care staff in developmental disabilities residential facilities in the United States: II. Turnover. Mental Retardation, 32, 34-42.

Peters-Scheffer, N., Didden, R., Korzilius, H., \& Sturmey, P. (2011). A meta-analytic study on the effectiveness of comprehensive ABAbased early intervention programs for children with autism spectrum disorders. Research in Autism Spectrum Disorders, 5, 60-69. https:// doi.org/10.1016/j.rasd.2010.03.011.

Peters-Scheffer, N., Didden, R., Korzilius, H., \& Sturmey, P. (2013). Therapist characteristics predict discrete trial teaching procedural fidelity. Intellectual and Developmental Disabilities, 51, 263-272. https://doi.org/10.1352/1934-9556-51.4.263.

Reichow, B. (2012). Overview of meta-analyses on early intensive behavioral intervention for young children with autism spectrum disorders. Journal of Autism and Developmental Disorders, 42, 512 520. https://doi.org/10.1007/s10803-011-1218-9.

Reichow, B., \& Wolery, M. (2009). Comprehensive synthesis of early intensive behavioral interventions for young children with autism based on the UCLA young autism project model. Journal of Autism and Developmental Disorders, 39, 23-41. https://doi.org/10.1007/ s10803-008-0596-0.

Reichow, B., Barton, E. E., Boyd, B. A., \& Hume, K. (2012). Early intensive behavioral intervention (EIBI) for young children with autism spectrum disorders (ASD). Cochrane Database of Systematic Reviews, 10, 1-60. https://doi.org/10.1002/14651858. CD009260.pub2.

Schaufeli, W. B., Leiter, M. P., Maslach, C., \& Jackson, S. E. (1996). Maslach burnout inventory - general survey (MBI-GS). In C. Maslach, S. E. Jackson, \& M. P. Leiter (Eds.), Maslach burnout 
inventory manual (3rd ed.). Palo Alto: Consulting Psychologists Press.

Seninger, S., \& Traci, M. A. (2002). Direct service staff turnover in supported living arrangements: preliminary results and observations (rural disability and rehabilitation research progress report no. 17). Missoula: University of Montana Bureau of Business and Economic Research.

Sulek, R., Trembath, D., Paynter, J., Keen, D., \& Simpson, K. (2017). Inconsistent staffing and its impact on service delivery in ASD early-intervention. Research in Developmental Disabilities, 63, 18-27. https://doi.org/10.1016/j.ridd.2017.02.007.

Virues-Ortega, J. (2010). Applied behavior analytic intervention for autism in early childhood: meta-analysis, meta-regression and doseresponse meta-analysis of multiple outcomes. Clinical Psychology Review, 30, 387-399. https://doi.org/10.1016/j.cpr.2010.01.008.

Waldman, J. D., Kelly, F., Arora, S., \& Smith, H. L. (2004). The shocking cost of turnover in heath care. Health Care Management Review, 29, 2-7.
Wise, M. D., Little, A. A., Holliman, J. B., Wise, P. H., \& Wang, J. (2010). Can state early intervention programs meet the increased demand of children suspected of having autism spectrum disorders? Journal of Developmental and Behavioral Pediatrics, 31, 469-476. https://doi.org/10.1097/DBP. 0b013e3181e56db2.

Zarafshan, H., Mohammadi, M. R., Ahmadi, F., \& Arsalani, A. (2013). Job burnout among Iranian elementary school teachers of students with autism: a comparative study. Iranian Journal of Psychiatry, 8 , $20-27$.

Publisher's Note Springer Nature remains neutral with regard to jurisdictional claims in published maps and institutional affiliations. 